\title{
EKSPLORASI STATUS RESISTENSI NYAMUK Aedes $S p$ TERHADAP INSEKTISIDA GOLONGAN ORGANOFOSFAT SECARA BIOKIMIA DI KABUPATEN BANYUMAS TAHUN 2017
}

\author{
Aryanti Puspitasari *), Aris Santjaka ${ }^{* *}$, Arif Widyanto $\left.{ }^{* * *}\right)$ \\ Jurusan Kesehatan Lingkungan, Politeknik Kesehatan Kemenkes Semarang, \\ Jl.Raya Baturaden KM 12 Purwokerto, Indonesia
}

\begin{abstract}
Abstrak
Jumlah kasus DBD pada tahun 2016 meningkat tajam bila dibandingkan tahun 2015 di Kabupaten Banyumas. Penggunaan insektisida telah dilakukan untuk pengendalian vektor Demam Berdarah dalam waktu yang lama. Insektisida Golongan Organofosfat jenis malathion telah digunakan sejak tahun 1991 dan sudah tidak digunakan lagi sejak tahun 2013 di Kabupaten Banyumas. Penelitian ini bertujuan untuk mengetahui status resistensi terhadap insektisida golongan organofosfat pada populasi nyamuk Aedes $S p$ di Kabupaten Banyumas dengan uji biokimia. Jenis penelitian ini eksploratif. Metode penelitian menggunakan uji biokimia (uji mikroplat/ uji enzimatis). Peningkatan aktivitas enzim esterase dibaca dengan menggunakan ELISA reader dengan panjang gelombang 450 $\mathrm{nm}$. Hasil penelitian secara keseluruhan menunjukkan bahwa di Desa Kedungrandu nyamuk resisten $8,33 \%$, nyamuk toleran $66,67 \%$ dan rentan $25 \%$ sedangkan di Desa Sidamulih nyamuk toleran masih 90,9\% dan nyamuk rentan 9,1\%. Hasil uji statistik independent T-Test dengan nilai siginifilkansi $=0,565$, menunjukkan bahwa pemeriksaan kandungan enzim esterase di dalam tubuh nyamuk diantara kedua desa tersebut dinyatakan tidak ada perbedaan, artinya paparan insektisida organofosfat yang diterima oleh nyamuk Aedes $S p$ dikedua desa tersebut relatif sama.Kesimpulan penelitian yaitu status resistensi nyamuk Aedes Sp terhadap insektisida golongan organofosfat di Desa Kedungrandu 8,33\% nyamuk dinyatakan resisten sedangkan yang toleran Desa Sidamulih 1,36\% lebih tinggi dibandingkan Desa Kedungrandu. Disarankan kepada pemerintah Dinas Kesehatan Kabupaten Banyumas hendaknya pergantian insektisida menggunakan insektisida yang belum pernah digunakan dalam program pengendalian vektor penyakit DBD di Indonesia demi efektivitas dan keberhasilan program itu sendiri serta mengutamakan upaya pemberantasan sarang nyamuk di masyarakat.
\end{abstract}

Kata kunci: Aedes $S p$; Organofosfat; Resistensi

\begin{abstract}
EXPLORATION OF Aedes Sp MOSQUITO RESISTENCE STATUS AGAINST ORGANOPHOSPHAT INSECTICIDE BIOCHEMICALLY IN BANYUMAS DISTRICT YEAR OF 2017. The number of case DBD in 2016 increase comparison in 2015 at District. Utilisinng insecticide has been used to contol the vector of DBD for a long time. Orgsnophosphate insecticide type of malathion has been used since 1991 and not used again since 2013 at Banyumas District. This research a purpose to find out of resistence status of population Aedes Sp to organophosphate insecticide class at Banyumas District with biochemical assay. The type of this research is explorative. The research method used biochemical assay (microplate assays). Increase of activitity enzim esterase using Elisa reader with wavelength of $450 \mathrm{~nm}$.Overall, the result of this research in Kedungrandu Village show that $8,33 \%$ mosquito are resistence, 66,67\% mosquito are tolerant and 25\% mosquito are susceptible. Thereafter in Sidamulih Village 90,9\% mosquito are still tolerant and mosquito susceptible are 9,1\%. The statistic of result with independent $t$-test significance $=0,565$, show that examination of esterase enzyme activity of these mosquitoes between two villages there is no different. it's means that effect of organophosphate insecticide accepting by mosquito Aedes $\mathrm{Sp}$ at two village are relatively same.The conclusion is resistence status of mosquito Aedes Sp with organophospate insecticide in Kedungrandu
\end{abstract}


Village 8,33\% are resistence and then in Sidamulih Village 1,36\% higher compared with Kedungrandu Village. Recommended to the Health district of Banyumas should be monitoring and evaluating the status of mosquito resistence to insecticide used and need replacement insecticide which has never been used for control of vector DHF in Indonesia for effectiveness and succes of the program as well as priority mosquito eradication efforts in the community.

Keywords: Aedes Sp; Organophosphate; Resistence

\section{Pendahuluan}

Permenkes RI Nomor 50 Tahun 2017 tentang Standar Baku Mutu Kesehatan Lingkungan dan Persyaratan Kesehatan untuk Vektor dan Binatang Pembawa Penyakit Serta Pengendaliannya bahwa penyakit menular melalui Vektor dan Binatang Pembawa Penyakit, kini masih menjadi masalah kesehatan masyarakat di Indonesia dengan angka kesakitan dan kematian yang cukup tinggi serta berpotensi menimbulkan Kejadian Luar Biasa (KLB) dan/ atau wabah serta memberikan dampak kerugian ekonomi masyarakat, sehingga perlu dilakukan upaya pengendalian Vektor dan Binatang Pembawa Penyakit. Salah satu penyakit yang dapat menimbulkan Kejadian Luar Biasa (KLB) dan/ atau wabah yaitu Demam Berdarah Dengue (DBD).

Tahun 2016 terdapat jumlah kasus DBD di Indonesia yang dilaporkan sebanyak 204.171 kasus dengan jumlah kematian sebanyak 1.598 orang. Jumlah kasus DBD tahun 2016 meningkat dibandingkan jumlah kasus tahun 2015 (129.650 kasus). Jumlah kematian akibat DBD tahun 2016 juga meningkat dari tahun 2015 (1.071 kematian). Incidence Rate (IR)/ angka kesakitan DBD tahun 2016 juga meningkat dari tahun 2015, yaitu 50,75 menjadi 78,85/ 100.000 penduduk. Namun, Case Fatality Rate (CFR) mengalami penurunan dari $0,83 \%$ pada tahun 2015 menjadi 0,78\% pada tahun 2016 (Profil Kesehatan Indonesia Tahun 2016).

Penyakit DBD masih merupakan permasalahan serius di Provinsi Jawa Tengah, berdasarkan hasil pendataan dari Dinas Kesehatan Provinsi Jawa Tengah, terbukti 35 kabupaten/kota sudah pernah terjangkit penyakit DBD. Angka kesakitan/ Incidence Rate (IR) DBD di Provinsi Jawa Tengah pada tahun 2016 sebesar 43,4/ 100.000 penduduk, mengalami penurunan bila dibandingkan dengan tahun 2015 yaitu 47,9/ 100.000 penduduk dan angka kematian/ Case Fatality Rate (CFR) DBD di Jawa Tengah tahun 2016 sebesar $1,46 \%$ menurun bila dibandingkan CFR tahun 2015 yaitu 1,56 persen.

\footnotetext{
${ }^{*}$ E-mail: aryanti.puspitasari@gmail.com

$\left.{ }^{* *}\right)$ E-mail: arissantjaka@gmail.com

${ }^{* * *)}$ E-mail: arifwidyanto74@yahoo.com
}

Pada tahun 2016, kematian akibat penyakit DBD terjadi di hampir seluruh kabupaten/ kota di Jawa Tengah. Hanya dua kabupaten/ kota yang melaporkan tidak terjadi kematian akibat DBD yaitu Wonosobo dan Kota Pekalongan (Dinas Kesehatan Provinsi Jawa Tengah Tahun 2016).

Angka kesakitan/ Incidence Rate (IR) di Kabupaten Banyumas pada tahun 2016 sebesar 49,0/100.000 penduduk dengan jumlah kasus 990. Hal ini meningkat tajam bila dibanding tahun 2015 sebesar 13,6/ 100.000 penduduk dengan jumlah kasus 264. Angka IR di Kabupaten Banyumas tahun 2016 masih diatas target nasional yaitu $<2 / 100.000$ penduduk. Angka kematian/ Case Fatality Rate (CFR) pada tahun 2016 adalah sebanyak 1 orang atau 1,6\% (Profil Kesehatan Kabupaten Banyumas Tahun 2016).

Pengendalian kimia dengan menggunakan insektisida banyak digunakan oleh masyarakat karena dapat menurunkan populasi nyamuk dengan cepat dan penggunaannya praktis, tetapi penggunaan insektisida terbukti banyak menimbulkan dampak negatif, antara lain matinya organisme bukan sasaran, adanya residu sehingga terjadi pencemaran lingkungan serta munculnya nyamuk yang resisten (Tarumingkeng, 1992 dalam Agustinus, 2010). Perkembangan resistensi dapat terjadi akibat seringnya dilakukan penggunaan insektisida terutama penyemprotan insektisida (fogging focus) pada wilayah kasus DBD. Bertambahnya jumlah kasus DBD, maka jumlah fogging focus juga ditingkatkan.

Penelitian yang dilakukan oleh Irawan Endy Pratama tahun 2016 di Desa Sidamulih Kecamatan Rawalo, bahwa hasil analisis statistik antara sebelum fogging focus pertama dengan 3 hari setelah fogging focus pertama menunjukkan beda mean $=.61765$ dengan $p=0,474 \quad(p>0,05)$ hasil tersebut tidak signifikan, artinya tidak ada beda densitas nyamuk sebelum fogging pertama dengan 3 hari setelah fogging pertama. Hasil analisis statistik antara sebelum fogging focus pertama dengan 3 hari setelah fogging focus kedua menunjukkan beda mean $=-.29412$ dengan $\mathrm{p}=0,733 \quad(\mathrm{p}>0,05)$, artinya tidak ada beda densitas nyamuk sebelum fogging pertama dengan 3 hari setelah fogging kedua, 3 hari setelah fogging focus kedua mengalami peningkatan. Hal itu menjadi indikasi adanya resistensi nyamuk Aedes $s p$ terhadap 
insektisida tertentu di Desa Sidamulih sedangkan penelitian yang dilakukan oleh Elsa Endiyani tahun 2016 di Desa Kedungrandu Kecamatan Patikraja diketahui bahwa, densitas nyamuk 2 hari sebelum fogging petama 71 ekor dan 6 hari setelah fogging kedua 24 ekor. Presentase penurunan sebesar 66,1\%, dapat disimpulkan secara nyata pelaksanaan fogging focus dapat menurunkan densitas nyamuk 6 hari setelah pelaksanaan fogging focus siklus kedua, tetapi berdasarkan hasil uji One Way Anova menunjukkan P value $=.056>\alpha 0,05 . \mathrm{P}$ value $=.056$, nilai ini hampir atau mendekati nilai $\alpha \quad 0,05$ kesimpulannya Ho diterima karena perbedaan tidak signifikan. Sehingga secara statistik tidak ada pengaruh fogging focus terhadap penurunan densitas nyamuk.

Malathion merupakan jenis insektisida golongan organofosfat dan paling sering digunakan. Menurut penuturan pemegang program Demam Berdarah Dengue Dinas Kesehatan Kabupaten Banyumas, malathion telah digunakan sebagai insektisida sejak tahun 1991. Berdasarkan data dari Dinas Kesehatan Kabupaten Banyumas dari tahun 2010 sampai dengan 2014 telah dilakukan 330 kali pelaksanaan fogging focus di Kabupaten Banyumas dimana lebih dari $50 \%$ atau 183 kali diantaranya menggunakan insektisida malathion. Dari total fogging focus dengan insektisida malathion di Kabupaten Banyumas dari tahun 2010 sampai 2014, 43\% atau 78 kali diantaranya dilaksanakan di Kota Purwokerto (Dinas Kesehatan Banyumas, 2014 dalam Irawan Endy, 2016). Insektisida organofosfat melalui aplikasi fogging bekerja dengan menghambat enzim asetilkolinesterase, sehingga terjadi penumpukan asetilkolin yang berakibat terjadinya kekacauan pada sistem pengantar impuls saraf ke sel-sel otot. Keadaan ini menyebabkan impuls tidak dapat diteruskan, otot menjadi kejang, dan akhirnya terjadi kelumpuhan (paralisis) dan akhirnya serangga mati. Penggunaan insektisida organofosfat dalam waktu lama dapat berakibat pada resistensi nyamuk terhadap organofosfat tersebut. Hal ini didasarkan pada pernyataan Georgio dan Melon dalam Heni prasetyowati (2016) yang menyebutkan bahwa penggunaan insektisida kimia dalam jangka lama dengan frekuensi yang tinggi secara bertahap akan menekan dan menyeleksi serangga (nyamuk vektor) sasaran untuk menjadi toleran sampai resisten terhadapnya. Pengelolaan penggunaan insektisida untuk pengendalian vektor dalam satuan ekoepidemiologi tidak bisa menggunakan insektisida dengan jenis dan cara kerja (mode of action) yang sama secara terus menerus. Pergantian jenis dan cara insektisida untuk ngendalian vektor harus dilakukan dalam periode waktu maksimal 2-3 tahun atau 4-6 kali aplikasi (Kemenkes, 2013).
Resistensi Ae. aegypti terhadap insektisida golongan organofosfat telah dilaporkan oleh Heni Prasetyowati di Tiga Kotamadya DKI Jakarta pada tahun 2016, kemudian di Jawa Tengah seperti di Kota Semarang, Kabupaten Kendal, Grobogan dan Purbalingga dilaporkan oleh Sunaryo dkk pada tahun 2014. Hasil penelitian oleh Kartini Lidia dan Elisabeth Levina Sari Setianingrum tahun 2008 tentang uji biokemis terhadap nyamuk Ae.albopictus di daerah Palu disimpulkan bahwa nyamuk tersebut sebagian besar 99,58\% telah toleran (resisten sedang) sedangkan $0,92 \%$ telah resisten (resisten tinggi) terhadap insektisida organofosfat (malation dan temefos).

Diperlukan adanya deteksi resistensi vektor terhadap insektisida di Kabupaten Banyumas adapun beberapa jenis uji resistensi salah satunya uji resistensi dengan menggunakan biokimia. Tujuan penellitian yaitu mengetahui status resistensi nyamuk Aedes sp sebagai vektor utama DBD terhadap insektisida organofosfat dI Kabupaten Banyumas.

\section{Bahan dan Metode}

Jenis penelitian yang digunakan adalah penelitian eksploratif untuk mengetahui status resistensi nyamuk Aedes $S p$ terhadap insektisida golongan organofosfat di Kabupaten Banyumas tahun 2017, karena di Kabupaten Banyumas belum pernah dilakukan uji resistensi. Nyamuk uji yang digunakan dari hasil penangkapan dengan menggunakan ovitrap, pemasangan ovitrap dilakukan di Desa Kedungrandu Kecamatan Patikraja dan Desa Sidamulih Kecamatan Rawalo radius $100 \mathrm{~m}$ dari rumah indeks kasus. Hasil penangkapan telur nyamuk yang diperoleh kemudian dibawa ke Laboratorium Entomologi Balai Litbang P2B2 Banjarnegara untuk dilakukan proses rearing hingga menjadi nyamuk dewasa F1 dan uji resistensi nyamuk Aedes $S p$ terhadap insektisida organofosfat

\section{Hasil dan Pembahasan}

\section{a. Prevalensi Kasus DBD}

Analisis prevalensi dilakukan untuk mengetahui seberapa sering kasus Demam Berdarah Dengue (DBD) terjadi di Desa Kedungrandu Kecamatan Patikraja dan Desa Sidamulih Kecamatan Rawalo. Prevalensi di dapatkan dari perhitungan jumlah kasus baru ditambahkan dengan jumlah kasus lama dibagi jumlah penduduk kemudian dikalikan dengan 100\%. Pada tahun 2015 jumlah kasus DBD di wilayah Kecamatan Patikraja terdapat 32 kasus, salah satu desa yang mempunyai kasus DBD yang banyak adalah Desa Kedungrandu dengan 5 kasus, maka prevalensinya adalah 0,06. Pada tahun 2016 kasus DBD di wilayah Kecamatan Rawalo terdapat 83 
kasus, salah satu desa yang mempunyai kasus DBD yang banyak adalah Desa Sidamulih sebanyak 7 kasus, maka prevalensinya adalah 0,1 .

Lokasi Desa Kedungrandu terletak langsung pada tepi jalan nasional, dekat dengan sungai, sedangkan Desa Sidamulih jauh dari tepi jalan nasional dan didaerah perbukitan. Ketinggian tempat di kedua desa tersebut masih dibawah $1000 \mathrm{~m}$ keadaan tersebut berpotensi menjadi tempat perkembangbiakannya nyamuk. Wilayah dengan ketinggian di atas $1.000 \mathrm{~m}$ tidak dapat ditemukan nyamuk karena pada ketinggian tersebut suhu terlalu rendah sehingga tidak memungkinkan bagi kehidupan nyamuk hidup. Suhu rata-rata harian di kedua desa tersebut masih lebih dari $10^{\circ} \mathrm{C}$ atau masih kurang dari $40^{\circ} \mathrm{C}$, pada suhu tersebut nyamuk masih mampu berkembangbiak. Kategori curah hujan Desa Kedungrandu dan Desa Sidamulih ter masuk kategori curah hujan sedang karena masih dibawah $3000 \mathrm{~mm}$. Penyebaran kasus DBD di Desa Kedungrandu dan Desa Sidamulih sangat dipengaruhi oleh letak geografisnya yang berpotensi mejadi tempat perkembangan vektor DBD yaitu nyamuk.

\section{Jumlah Penderita}

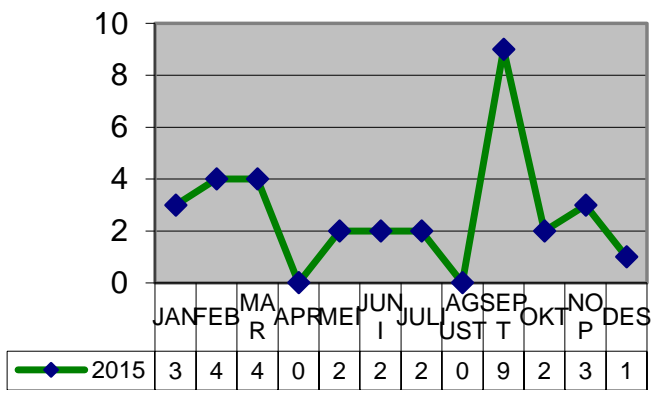

Gambar 1. Grafik Bulanan Kasus DBD di Desa Kedungrandu Tahun 2015

(Sumber: Data Puskesmas Patikraja Tahun 2015)

Kasus DBD di Desa Kedungrandu tertinggi pada Bulan September dapat dilihat pada gambar 1, hal ini disebabkan kondisi lingkungan di sekitar Desa Kedungrandu mempunyai potensi penularan kasus DBD. Lokasi Desa Kedungrandu langsung berada ditepi jalan nasional, bersebrangan dengan kebun maupun hutan, dekat dengan sungai dan banyak blukar. Kondisi fisik rumah-rumah responden masih jauh dari perilaku hidup bersih dan sehat, seperti sampah yang masih berserakan di pekarangan rumah, banyaknya barang-barang bekas yang sudah tidak digunakan di simpan dalam rumah dan juga menumpuk di sekitar rumah, hal ini dapat menjadi tempat perkembangbiakan (breeding place) dan tempat tinggal (resting place) nyamuk. Ehler dan Steel, 1990 dalam Lintje Boekoesoe, 2013 mengemukakan bahwa sanitasi lingkungan adalah usaha mencegah terjadinya suatu penyakit dengan cara menghilangkan atau mengatur faktor-faktor lingkungan yang berkaitan dengan rantai penularan. Berdasarkan pengertian ini maka sanitasi lingkungan mempunyai peranan besar terhadap terciptanya lingkungan yang sehat. Pada prinsipnya usaha sanitasi bertujuan untuk menghilangkan tempat perkembangbiakan (breeding place) dan tempat tinggal (resting place) yang sangat dibutuhkan vektor dan binatang pengganggu.

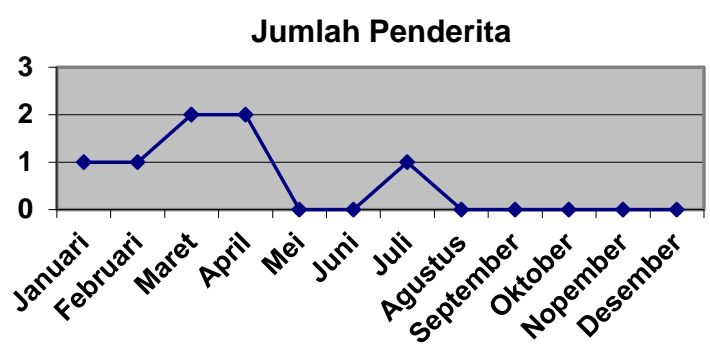

Gambar 2. Grafik Bulanan Kasus DBD di Desa Sidamulih Tahun 2016

(Sumber: Data Puskesmas Rawalo Tahun 2016)

Kasus DBD di Desa Sidamulih tertinggi pada Bulan Maret dan April dapat dilihat pada gambar 2, hal itu disebabkan karena pada Bulan Maret dan April adalah peralihan dari musim hujan ke musim kemarau. Curah hujan akan mempengaruhi naiknya kelembaban nisbi udara dan menambah jumlah tempat perkembangbiakkan/ breading places (Depkes RI, 2007). Intensitas curah hujan yang lebat diikuti dengan angin dalam waktu yang relatif lama, justru dapat menghilangkan tempat perindukan, karena aliran air yang deras membawa larva dalam tempat perindukan dan pada akhirnya larva akan mati atau hanyut pindah lokasi, dengan demikian siklus hidup nyamuk akan terputus mata rantainya. Hujan dengan intensitas tidak terlalu deras dan diselingi oleh panas, akan memperbanyak tempat perindukan, sehingga memperbesar kesempatan nyamuk untuk berkembang secara optimal (Depkes RI, 2007). Pengaruh intensitas curah hujan lainnya adalah bisa menigkatkan kandungan uap air di udara, sehingga kelembaban akan lebih tinggi, akibatnya usia nyamuk semakin panjang. Pada saat suhu udara yang panas akan menyebabkan frekuensi nyamuk menggigit lebih cepat karena tubuh nyamuk mengalami dua hal yaitu konveksi udara panas dan masuknya udara panas saat terjadi inspirasi oksigen, sementara nyamuk tidak mempunyai regulator pengaturan kelembaban tubuh, sistem kelembaban sangat tergantung pada cairan haemolymp yang terdiri dari asam amino, lemak protein, glukosa dll dengan masuknya udara panas dan 
konveksi panas terhadap tubuh nyamuk, maka evaporasi cairan haemolymp akan terjadi lebih cepat, dengan demikian nyamuk akan mengalami dehidrasi dan tubuhnya kering, inilah yang menyebabkan mortalitas nyamuk dalam jumlah besar (Aris Santjaka, 2013).

Tabel 1. Pengukuran Kondisi Lingkungan Fisik

\begin{tabular}{clcc}
\hline No & \multicolumn{1}{c}{ Desa } & $\begin{array}{c}\text { Suhu }\left({ }^{\mathbf{0}} \mathbf{C}\right) \\
\text { Rata-rata }\end{array}$ & $\begin{array}{c}\text { Kelembaban } \\
(\boldsymbol{\%}) \text { Rata-rata }\end{array}$ \\
\hline 1 & Kedungrandu & 28 & 91 \\
2 & Sidamulih & 31 & 86 \\
\hline
\end{tabular}

Sumber: Data Primer Terolah

Suhu rata-rata optimum untuk perkembangan nyamuk adalah $25^{\circ} \mathrm{C}-27^{\circ} \mathrm{C}$. Nyamuk tidak tahan pada suhu lebih dari $33^{\circ} \mathrm{C}$ (Manson's, 2009 dalam Aris Santjaka, 2013), karena siklus ekstrinsik agen terganggu pada tubuh nyamuk, sedangkan hasil penelitian dengan menggunakan estimasi $33,69^{\circ} \mathrm{C}$ itupun dengan catatan sinar matahari masuk ke permukaan tanah, sehingga mengurangi kelembaban. Hal ini disebabkan karena kelemahan fisiologis nyamuk itu sendiri. Nyamuk mengalami dehidrasi dan mati, sehingga agen tidak dapat menyelesaikan siklus ekstrinsiknya (Aris Santjaka, 2016). Pertumbuhan nyamuk akan terhenti sama sekali bila suhu kurang dari $10^{\circ} \mathrm{C}$ atau lebih dari $40^{\circ} \mathrm{C}$. Hasil pengukuran ratarata suhu di kedua desa dapat dilihat pada tabel 1 , hasil pengukuran tersebut melebihi suhu optimum untuk perkembangan nyamuk, tetapi masih dibawah suhu maksimal yaitu lebih dari $33^{\circ} \mathrm{C}$.

Hasil pengukuran dilapangan menunjukkan rata-rata kelembaban di kedua desa dapat dilihat pada tabel 1, hasil pengukuran tersebut berpotensi untuk perkembangan hidup nyamuk karena diatas $60 \%$. Nyamuk umumnya menyukai kelembaban diatas $60 \%$ (Martens, 1995 dalam Aris Santjaka, 2013). Pada kelembaban kurang dari $60 \%$ umur nyamuk akan menjadi lebih pendek, sehingga siklus sprogoninya tidak terbentuk (Depkes RI, 2007). Menurut Sukowati (2010) dalam Gustina Fajarwati (2014) adanya peningkatan suhu dan kelembaban udara dapat mempengaruhi bahkan merubah perilaku menggigit dan rata-rata angka gigitan (bitting rate) suatu populasi nyamuk. Kondisi tersebut juga memicu semakin cepatnya perkembangbiakan nyamuk dan semakin pendeknya masa kematangan parasit nyamuk (Hidriyah, 2010).

\section{b. Indikator Potensi Penularan}

Kepadatan populasi nyamuk di suatu daerah dapat menggambarkan potensi penularan DBD, salah satu cara yaitu yang bisa dilakukan dengan mengukur ovitrap index (Oi)nya (WHO, 1997 dalam Siwi Pramatama, dkk, 2017). OI menggambarkan jumlah ovitrap yang positif telur dari sejumlah ovitrap yang diobservasi. OI ini menjadi cara menggambarkan aktivitas bertelur nyamuk dewasa baik di dalam maupun di luar rumah. Angka ini bisa untuk menambah informasi dari survey jentik seperti House Index (HI), Breteau Index (BI) dan Container Index (CI).

Tabel 2. Hasil Pemasangan Ovitrap di Lokasi Penelitian

\begin{tabular}{llcccc}
\hline No & \multicolumn{1}{c}{ Desa } & $\begin{array}{c}\text { Jumlah } \\
\text { Rumah }\end{array}$ & $\begin{array}{c}\text { Jumlah } \\
\text { Ovitrap }\end{array}$ & $\begin{array}{c}\text { Ovitrap } \\
\text { positif }\end{array}$ & $\begin{array}{c}\text { Indeks } \\
\text { Ovitrap }\end{array}$ \\
\hline $\begin{array}{l}\text { Kedungran- } \\
\text { 2. }\end{array}$ & 23 & 46 & 15 & 34,7 \\
du & Sidamulih & 39 & 78 & 10 & 12,8 \\
\hline Jumlah & 62 & 124 & 25 & 47,5 \\
\hline
\end{tabular}

Sumber: Aris Santjaka 2017

Hasil ovitrap index seperti yang ditunjukkan pada tabel 2, dari kedua desa tersebut OI Desa Kedungrandu 1,5 lebih besar dibandingkan dengan Desa Sidamulih.

Tabel 3. Densitas Larva Nyamuk

\begin{tabular}{cccccc}
\hline No & Desa & $\begin{array}{c}\text { HI } \\
(\boldsymbol{\%})\end{array}$ & $\begin{array}{c}\text { CI } \\
(\boldsymbol{\%})\end{array}$ & $\begin{array}{c}\text { BI } \\
(\boldsymbol{\%})\end{array}$ & $\begin{array}{c}\text { ABJ } \\
(\boldsymbol{\%})\end{array}$ \\
\hline 1. & Kedungrandu & 25 & 77,78 & 35 & 75 \\
2. & Sidamulih & 7,69 & 55,55 & 12,8 & 92,3 \\
\hline \multicolumn{2}{l}{ Ratio } & 3,25 & 1,40 & 2.73 & 0,84 \\
\hline
\end{tabular}

Sumber: Aris Santjaka 2017

Nilai HI, CI dan BI Desa Kedungrandu lebih tinggi dibandingkan dengan Desa Sidamulih, kecuali nilai ABJ Desa Kedungrandu yang lebih rendah daripada Desa Sidamulih. Nilai ABJ Desa Kedungrandu yang relatif rendah (kurang dari 95\%) memperbesar peluang terjadinya transmisi virus DBD (Hasyimi dkk, 2005 dalam Ary Oktsari Y.S, 2012), sedangkan nilai ABJ Desa Sidamulih walaupun masih dibawah $\geq 95 \%$ tetapi sudah mendekati angka tersebut, maka kebersihan di lingkungan yang diperiksa lebih ditingkatkan lagi, sehingga resiko terjadinya DBD semakin berkurang. Berdasarjkan hasil perhitungan kepadatan jentik (density figure) yang dihitung berdasarkan nilai HI, CI, dan BI kemudian dikategorikan menjadi kepadatan rendah, sedang dan tinggi menggunakan kriteria dari Queensland Government (2011) dalam Arum Sih Joharina (2014), Desa Kedungrandu memiliki kategori density figure tinggi sedangkan Desa Sidamulih memiliki kategori density figure sedang. Pada CI dan BI semakin banyak jumlah container yang positif (+) jentik maka hal ini dapat mengindikasi masyarakat yang masih kurang dalam mengendalikan nyamuk Aedes $S p$ di desa tersebut, apabila hal ini dibiarkan maka akan 
menjadikan Desa Kedungrandu menjadi daerah yang mempunyai resiko penularan tinggi DBD.

Tingginya indeks ovitrap, HI, BI, CI dan density figure di Desa Kedungrandu harus menjadi perhatian karena dimungkinkan angka kepadatan nyamuknya juga akan tinggi. Kepadatan nyamuk yang tinggi dapat berpotensi untuk menularkan virus dengue. Apabila terdapat penderita DBD di daerah dengan kepadatan nyamuk yang tinggi, potensi untuk dapat menyebar ke sekelilingnya juga tinggi karena adanya vektor yang kompeten (Scott dan Marrison, 2010 dalam Siwi Pramatama, 2017).

\section{c. Hasil Uji Resistensi Secara Biokimia}

Uji biokimia untuk melihat aktivitas enzim esterase yang berfungsi mengidentifikasi mekanisme yang mendasari terjadinya resistensi serangga terhadap insektisida golongan organofosfat. Kelemahan dari uji biokimia adalah hanya dapat mendeteksi resistensi berdasarkan golongan insektisida, tidak dapat mendeteksi berdasarkan jenis insektisidanya. Terjadinya resistensi ditandai dengan adanya peningkatan aktivitas enzim yang dapat diketahui dari pengukuran absorbansinya.

Mekanisme resistensi insektisida mempunyai suatu dasar biokimia (Brogdon dan McAllister, 1998 dalam Marisa, 2007). Terdapat dua bentuk biokimia sebagai sisi target resistensi terhadap insektisida yang terjadi ketika insektisida tidak lagi berikatan dengan target dan terjadi detoksifikasi oleh enzim esterase yang mencegah insektisida mencapai sisi target asamasam amino yang merupakan pengikat insektisida pada sisi-sisi aktifnya menyebabkan insektisida tersebut kurang atau menjadi tidak efektif. Pada serangga adanya enzim esterase sangat penting, karena fungsinya untuk mendetoksifikasi insektisida. Enzim esterase mempunyai sifat bekerja sangat cepat dalam mengikat titik tangkapnya dan lambat dalam memulihkan kembali kedalam keadaan normal. Secara ringkasnya, enzim ini lebih cepat dalam mengikat toksin insektisida dibandingkan dengan memetabolisme insektisida tersebut. (Hemingway and Ranson, 2000 dalam Dwi Jayanti Gunandhini dan P.B Wicaksana, 2005).

Uji Biokimia menggunakan 24 sampel nyamuk hasil dari pembiakkan telur dari setiap rumah yang ditemukannya telur dikedua desa, 13 sampel rumah dari Desa Kedungrandu dan 11 sampel rumah dari Desa Sidamulih. Proses penentuan aktivitas enzim esterase secara biokimia yaitu : sampel nyamuk digerus dengan menggunakan alat homogenisator hingga menjadi homogenat kemudian sampel nyamuk

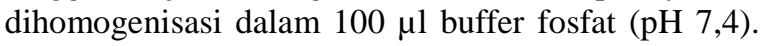
Sebanyak $20 \mu \mathrm{l}$ aliquot dari homogenate masingmasing nyamuk dimasukkan dalam sumuran microplate lalu ditambahkan $50 \mu \mathrm{l}$ substrat $\alpha$-nafthyl asetat. Selanjutnya pada masing-masing sumuran ditambahkan $50 \mu \mathrm{l}$ coupling raagent sebagai indikator warna. Microplate diinkubasi selama 10 menit pada suhu ruang. Intensitas warna yang dihasilkan pada masing-masing sumuran diukur absorbansinya menggunakan ELISA reader.

Malathion $0,8 \%$ telah digunakan sebagai insektisida sejak tahun 1991. Berdasarkan data dari Dinas Kesehatan Kabupaten Banyumas dari tahun 2010 sampai dengan 2014 telah dilakukan 330 kali pelaksanaan fogging focus di Kabupaten Banyumas dimana lebih dari $50 \%$ atau 183 kali diantaranya menggunakan insektisida malathion $0.8 \%$. Dari total fogging focus dengan insektisida jenis malathion $0,8 \%$ di Kabupaten Banyumas dari tahun 2010 sampai 2014, 43\% atau 78 kali diantaranya dilaksanakan di Kota Purwokerto (Dinas Kesehatan Banyumas, 2014 dalam Irawan Endy, 2016).

Tabel 4. Hasil Uji Resistensi Berdasarkan Desa

\begin{tabular}{lcccc}
\hline \multirow{2}{*}{ Kategori } & \multicolumn{4}{c}{ Desa } \\
\cline { 2 - 5 } & \multicolumn{2}{c}{ Kedungrandu } & \multicolumn{2}{c}{ Sidamulih } \\
\cline { 2 - 5 } & $\boldsymbol{\Sigma}$ & $\boldsymbol{\%}$ & $\boldsymbol{\Sigma}$ & $\boldsymbol{\%}$ \\
\hline Rentan & 3 & 25 & 1 & 9,1 \\
Toleran & 8 & 66,67 & 10 & 90,9 \\
Resisten & 2 & 8,33 & 0 & 0 \\
\hline Jumlah Sampel & 12 & 100 & 11 & 100 \\
\hline
\end{tabular}

Sumber: Aris Santjaka 2017

Hasil penelitian sebagaimana pada tabel 4 yang menunjukkan resistensi yaitu Desa Kedungrandu sebesar 8,33\% sedangkan yang toleran Desa Sidamulih $1,36 \%$ lebih tinggi dibandingkan dengan Desa Kedungrandu. Insektisida golongan organofosfat jenis malathion terakhir digunakan pada tahun 2013 di Desa Kedungrandu dan di Desa Sidamulih, kemudian di rotasi dengan menggunakan insektisida golongan pyretroid yaitu jenis cypermethrin. Hal tersebut diketahui bahwa insektisida golongan organofosfat yaitu malathion sudah tidak digunakan lagi selama 5 tahun, dengan demikian walaupun insektisida itu sudah lama tidak digunakan proses resistensi itu bersifat permanen. Penelitian ini membantah teori rotasi, menurut Kementerian Kesehatan tahun 2013 mengenai pengelolaan penggunaan insektisida yaitu salah satunya dengan melakukan rotasi penggunaan insektisida untuk mengurangi daya resistensi terhadap insektisida tersebut harus dilakukan rotasi dalam periode waktu tertentu, karena mekanisme reduksi akan mengurangi kandungan insektisida dalam tubuh nyamuk melalui sistem ekskresi. Tetapi faktanya berbalik dengan menyatakan resistensi bersifat permanen. Permanennya resistensi nyamuk dapat dijelaskan melalui mekanisme biomolekuler. 
Mekanisme biomolekuler melihat resistensi dari sisi yang terjadi pada rangkaian molekul baik dalam sel maupun kromosom. Penyakit yang ditularkan melalui vektor mengalami double burden, beban pertama berupa tekanan di manusia yaitu dengan menggunakan obat-obatan, beban kedua terletak di tubuh nyamuk yaitu berupa harus menghadapi jenis insektisida yang sudah dipaparkan dalam waktu yang cukup lama (Aris Santjaka, 2016). Lama penggunaan insektisida yang sama atau sejenis dalam waktu yang lama secara terus menerus dapat mempengaruhi resistensi terhadap insektisida Aplikasi insektisida yang terus menerus akan merangsang terjadinya perubahan gen-gen pada tubuh menjadi gen-gen yang resisten. Perilaku nyamuk yang sering berimigrasi ke daerah lain dalam radius 100 meter dan jumlah insektisida yang disemprotkan, hal ini berpengaruh juga terhadap evolusi resistensi nyamuk di daerah tersebut. Pengaruh migrasi ini akan terjadi jika nyamuk yang mempunyai gen resisten bertelur di tempat lain sehingga akan terdapat generasi dari nyamuk tersebut yang membawa sifat resisten (Rizki Anindita dan Tri Wulandari, 2007).

Uji statistik digunakan untuk mengetahui perbedaaan nilai ELISA reader diantara kedua desa, sehingga diketahuii daya paparan keduanya yang hasilnya sebagai berikut;

Tabel 5. Hasil Uji Statistik

\begin{tabular}{lccc}
\hline \multicolumn{1}{c}{ Desa } & $\begin{array}{c}\text { Rata-rata } \\
\text { Panjang } \\
\text { Gelombang }\end{array}$ & Signifikansi & Kesimpulan \\
\hline Kedungrandu & 0,72039 & 0,565 & Ho diterima \\
Sidamulih & 0,75255 & & \\
\hline
\end{tabular}

Sumber: Aris Santjaka 2017

Hasil uji statistik dinyatakan kandungan enzim di kedua desa relatif sama dengan nilai signifikansi 0,565, sebagaimana ditunjukkan pada tabel 5, hal itu disebabkan karena di kedua desa tersebut sudah mengalami paparan insektisida yang sama sehingga menghasilkan enzim esterase, terdapat dua bentuk biokimia sebagai sisi target resistensi terhadap insektisida yang terjadi ketika insektisida tidak lagi berikatan dengan target dan terjadi detoksifikasi oleh enzim esterase yang mencegah insektisida mencapai sisi target asam-asam amino yang merupakan pengikat insektisida pada sisi-sisi aktifnya menyebabkan insektisida tersebut kurang atau menjadi tidak efektif sehingga nyamuk tidak mati ketika terkena paparan insektisida.

Hal ini terjadi juga di Kabupaten Pekalongan, penelitian yang dilakukan oleh Ikawati tahun 2016, hasil pengamatan aktivitas enzim esterase pada populasi nyamuk dari ketiga desa menunjukkan bahwa persentase nyamuk yang mengalami peningkatan aktivitas enzim esterase yang paling besar ada di Desa Simbangkulon dan Desa Kedungwuni Barat, yaitu $62,5 \%$ untuk masing-masing desa. Sedangkan Desa Karangsari persentase nyamuk yang mengalami peningkatan aktivitas enzim esterasenya lebih kecil (50\%). Masyarakat di Kabupaten Pekalongan menggunakan obat nyamuk bakar dengan bahan aktif transfluthrin 3\%. Selain itu malathion digunakan tahun 1998-2004 dan sudah tidak lagi digunakan sejak tahun 2004. Hal ini menunjukkan bahwa populasi nyamuk Ae.aegypti di Kabupaten Pekalongan sudah relatif jarang terpapar malathion dalam 5 tahun terakhir. Namun sifat resisten terhadap malathion masih ditemukan pada populasi nyamuk Ae.aegypti di Kabupaten Pekalongan.

Berdasarkan penelitian yang telah dilakukan, diharapkan hasil penelitian ini sebagai bahan informasi dan pertimbangan untuk Institusi Pemerintahan Kabupaten Banyumas dalam manajemen penggunaan insektisida, apabila ingin melakukan pergantian insektisida yang akan digunakan selanjutnya demi keberhasilan pengendalian vektor DBD.

\section{Simpulan}

Kondisi lingkungan fisik yang telah diukur meliputi suhu dan kelembaban. Rerata suhu di Desa Kedungrandu $28^{\circ} \mathrm{C}$ sedangkan di Desa Sidamulih $31^{\circ} \mathrm{C}$. Rerata kelembaban di Desa Kedungrandu $91 \%$ sedangkan di Desa Sidamulih $86 \%$.

Indeks larva nyamuk Aedes $S p$ yang diukur meliputi HI, BI, CI dan ABJ, di Desa Kedungrandu $\mathrm{HI}=25 \%, \mathrm{BI}=35 \%, \mathrm{CI}=77,78 \%$ dan $\mathrm{ABJ}=75 \%$ sedangkan di Desa Sidamulih $\mathrm{HI}=7,69 \%, \mathrm{BI}=12,8 \%$, $\mathrm{CI}=55,55 \%$ dan $\mathrm{ABJ}=92,3 \%$.

Status resistensi nyamuk Aedes $S p$ terhadap insektisida golongan organofosfat di Kabupaten Banyumas secara biokimia didapatkan hasil bahwa di Desa Kedungrandu kondisi nyamuk kategori resisten $8,33 \%$, kategori toleran $66,67 \%$ dan kategori rentan $25 \%$ sedangkan di Desa Sidamulih kondisi nyamuk kategori resisten $0 \%$, kategori toleran 90,9\% dan kategori rentan 9,1\%. Ditinjau dari uji statistiknya pemeriksaan kandungan enzim esterase di dalam tubuh nyamuk diantara kedua desa tersebut dinyatakan tidak ada perbedaan, artinya paparan insektisida organofosfat yang diterima oleh nyamuk Aedes $S p$ oleh dikedua desa tersebut relatif sama

\section{Saran}

Bagi instustusi pemerintahan Dinas Kesehatan Kabupaten hendaknya melakukan pergantian insektisida menggunakan insektisida yang belum pernah digunakan di wilayah tersebut dengan terlebih dahulu melakukan pengujian efektifitas insektisida tersebut. 
Bagi masyarakat, hendaknya tidak sembarangan memakai berbagai jenis insektisida karena akan mengakibatkan resistensi nyamuk, akan lebih baik kalau menggunakan metode Pemberantasan Sarang Nyamuk (PSN) seminggu sekali dan pencegahan seperti 3M+ (Menutup, menguras, menggunakan kembali, dan abatisasi). sebagai tindakan menghilangkan tempat breeding place dan resting place nyamuk vektor DBD.

\section{Daftar Pustaka}

Adang Iskandar, dkk. 1985. Pedoman Bidang Studi Pemberantasan Serangga dan Binatang Pengganggu Akademi Penilik Kesehatan Teknologi Sanitasi (APK-TS). Jakarta: Pusat Pendidikan Tenaga Kesehatan Depkes RI

Agustinus. 2010. Status Kerentanan Nyamuk Aedes aegypti Terhadap Insektisida Malation Di Kota Surabaya. Thesis. Bogor: Institut Pertanian Bogor, at http://repository.ipb.ac.id/jspui/bitstream/12345 6789/56009/8/Cover.pdf diakses pada tanggal 22 Oktober 2017 pukul 20.20 WIB

Aris Santjaka. 2013. Malaria Pendekatan Model Kausalitas. Yogyakarta: Nuha Medika 2016. Zika dalam Perspektif Vektor dan Upaya Pengendaliannya. Purwokerto: Politeknik Kesehatan Semarang Jurusan Kesehatan Lingkungan Purwokerto

Arum Sih Joharina, Widiarti. 2014. Kepadatan Larva Nyamuk Vektor sebagai Indikator Penularan Demam Berdarah Dengue di Daerah Endemis di Jawa Timur. Jurnal Vektor Penyakit, Vol.8 No.2:33-40, at http://ejournal.litbang.depkes.go.id/index.php/v ektorp/article/view/3637 diakses pada tanggal 13 Januari 2018 pukul 10.31

Chasan Sudjain Kusnadi. 2006. Pengendalian Vektor dan Binatang Pengganggu (Vecto Control Manual). Makassar: Institut Penerbitan Jurusan Kesehatan Lingkungan Poltekkes Makassar

Departemen Kesehatan Republik Indonesia. 2001. Pedoman Ekologi dan Aspek Perilaku Vektor. Jakarta: Direktorat Jenderal Pengendalian Penyakit Dan Penyehatan Lingkungan

2007. Ekologi dan Aspek Perilaku Vektor. Jakarta: Direktorat Jenderal Pengendalian Penyakit Dan Penyehatan Lingkungan
2013. Pedoman Pengendalian Demam Berdarah Dengue Di Indonesia. Jakarta: Direktorat Jenderal Pengendalian Penyakit Dan Penyehatan Lingkungan

Dwi Anggriani Wahyu Mukti. 2016. Resistensi Nyamuk Aedes aegypti Sebagai Vektor DBD Terhadap Bahan Aktif Racun Nyamuk Formulasi Bakar. Skripsi. Semarang: Universitas Muhammadiyah Semarang, at http://repository.unimus.ac.id/28/1/FULL\%20T EXT\%20fix.pdf diakses pada tanggal 23 Desember 2017 pukul 03.32 WIB

Dwi Jayanti Gunandini dan P.B. Wicaksana. 2005. Peningkatan dan Aktivitas Enzim Asetilkolinesterase Pada Nyamuk Aedes aegypti yang Di Seleksi dengan Malation. Jurnal Entomologi Indonesia, Vol.2 No.2, at https://peipusat.org/jurnal/index.php/jei/article/view/294/ D.J.Gunandini\%26P.B.Wicaksana.pdfdiakses pada tanggal 23 Desember 2017 pukul 03.20 WIB

Dyah Widiastuti, Bina Ikawati, 2016. Resistensi Malathion dan Aktivitas Enzim Esterase Pada Populasi Nyamuk Aedes aegypti di Kabupaten Pekalongan. Balai Litbang P2B2 Banjarnegara, Vol.12 No.2:61-70, at http://repository.unimus.ac.id/28/1/FULL\%20T EXT\%20fix.pdf diakses pada tanggal 02 Januari 2018 pukul 09.22 WIB

Elsa Endiyani. 2016. Kohort Densitas Nyamuk Pada Fogging Focus Di Desa Kedungrandu Kecamatan Patikraja Kabupaten Banyumas Tahun 2016. Karya Tulis Ilmiah. Purwokerto. Poltekkes Kemenkes Semarang

Esther Sri Majawati. 2017. Kerentanan Vektor Demam Berdarah Dengue Terhadap Insektisida Golongan Organofosfat. Jurnal Kedokteran Meditek, Vol.21 No. 56, at http://ejournal.ukrida.ac.id/ojs/index.php/Ked/a rticle/viewFile/1259/1320 diakses pada tanggal 02 Januari 2018 pukul 09.22 WIB

Evi Sulistyorini. 2016. Faktor Penentu Keberadaan Larva Aedes Spp. Pada Daerah Endemis Demam Berdarah Dengue Tertinggi dan Terendah di kota Bogor. Thesis. Bogor: Institut Pertanian Bogor, at http://repository.ipb.ac.id/handle/123456789/8 
2199 diakses pada tanggal 16 April 2018 pukul 07.24 WIB

Firda Yanuar Pradani, Mara Ipa, Rina Marina, Yuneu Yuliasih. 2011. Status Resistensi Aedes aegypti dengan Metode Susceptibility di Kota Cimahi terhadap Cypermethrin. Jurnal Aspirator Vol.3 No.1:18-24, at http://ejournal.litbang.depkes.go.id/index.php/a spirator/article/view/2955 diakses pada tanggal 20 Desember 2017 pukul 09.45 WIB

Gustina Fajarwati Sihombing, Irnawati Marsaulina, Taufik Ashar. 2014. Hubungan Curah Hujan, Suhu Udara, Kelembaban Udara, Kepadatan Penduduk Dan Luas Lahan Pemukiman Dengan Kejadian Demam Berdarah Dengue Di Kota Malang Periode Tahun 2002-2011. Jurnal USU Vol 3, No 1, at https://jurnal.usu.ac.id/index.php/lkk/article/vie w/4238 diakses pada tanggal 16 April 2018 pukul 06.56 WIB

Hamim Sudarsono. 2015. Pengantar Pengendalin Hama Tanaman. Yogyakarta: Plantaxia

Heni Prasetyowati, Joni Hendri, Tri Wahono. 2016. Status Resistensi Aedes aegypti ( Linn .) terhadap Organofosfat di Tiga Kotamadya DKI Jakarta. BALABA Vol.12 No.1: 23-30, at http://ejournal.litbang.depkes.go.id/index.php/b lb/article/viewFile/4454/4359 diakses pada tanggal 29 Desember 2017 pukul 02.21 WIB

Hasan Boesri, 2011. Biologi dan Peranan Aedes Albopictus (Skuse) 1894 sebagai Penular Penyakit. Jurnal Aspirator Vol. No. 2, at http://ejournal.litbang.depkes.go.id/index.php/a spirator/article/view/2966 diakses pada tanggal 02 Januari 2018 pukul 09.23 WIB

Irawan Endy Pratama. 2016. Kohort Evaluasi Nyamuk Dewasa Setelah Pelaksanaan Fogging foccus Di Desa Sidamulih Kecamatan Rawalo Kabupaten Banyumas Tahun 2016. Skripsi. Purwokerto : Politeknik Kesehatan Kemenkes Semarang.

Kartini Lidia, Elisabeth Levina Sari Setianingrum. 2008. Deteksi Dini Resistensi Nyamuk Aedes albopictus Terhadap Insektisida Organofosfat Di Daerah Endemis Demam Berdarah Dengue Di Palu (Sulawesi Tengah). Jurnal Media Kesehatan Masyarakat Vol.3 No.2:105-110. , at

https://mediakesehatanmasyarakat.files.wordpr ess.com/2012/06/artikel-6.pdf diakses pada tanggal 22 Desember 2017 pukul 23.32 WIB

Kementerian Kesehatan Republik Indonesia. 2012. Petunjuk Teknis Pemberantasan Sarang Nyamuk Demam Berdarah Dengue (PSN DBD) Oleh Juru Pemantau Jentik (Jumantik). Jakarta: Direktorat Jenderal Pengendalian Penyakit dan Penyehatan Lingkungan Direktorat Pengendalian Penyakit Bersumber Binatang

2012. Pedoman Penggunaan Insektisida (Pestisida) Dalam Pengendalian Vektor. Jakarta: Direktorat Jenderal Pengendalian Penyakit dan Penyehatan Lingkungan Jakarta

2013. Pedoman Pengendalian Demam Berdarah Dengue Di Indonesia. Jakarta: Direktorat Jenderal Pengendalian Penyakit Dan Penyehatan Lingkungan

Lintje Boekoesoe. 2013. Kajian Faktor Lingkungan Terhadap Kasus Demam Berdarah Dengue (DBD) Studi Kasus Di Kota Gorontalo Provinsi Gorontalo. Laporan Akhir Hibah Disertasi Doktor. Gorontalo: Universitas Negeri Gorontalo, http://repository.ung.ac.id/riset/show/2/949/kaji an-faktor-lingkungan-terhadap-kasus-demamberdarah-dengue-dbd-studi-kasus-di-kotagorontalo-provinsi-gorontalo.html diakses pada tanggal 16 April 2018 pukul 06.33 WIB

Marisa. 2007. Toleransi Larva Nyamuk Dewasa Aedes aegypti Terhadap Temefos dan Malation Di Wilayah Endemik Kelura han Duren Sawit Jakarta Timur. Skripsi. Bogor: Institut Pertanian Bogor, at https://textid.123dok.com/document/9ynj6gjz-toleransilarva-dan-nyamuk-dewasa-aedes-aegypti terhadap-temefos-dan-malation-di-wilayahendemik-kelurahan-duren-sawit-jakarta-timur1.html diakses pada tanggal 02 November 2017 pukul 19.30 WIB

Mutia Dwi Putri, Adrial Adrial, Lili Irawati. 2016. Hubungan Tindakan Pemberantasan Sarang Nyamuk (PSN) dengan Keberadaan Jentik Vektor Chikungunya di Kampung Taratak Paneh Kota Padang. Jurnal Kesehatan Andalas Vol.5, No. $\quad 3$ at http://jurnal.fk.unand.ac.id/index.php/jka/article /view/563 diakses pada tanggal 16 April 2018 pukul 07.40 WIB 
Peraturan Menteri Kesehatan Republik Indonesia Nomor 50 Tahun 2017 tentang Standar Baku Mutu Kesehatan Lingkungan dan Persyaratan Kesehatan untuk Vektor dan Binatang Pembawa Penyakit Serta Pengendaliannya

Rahmayanti Amini. 2016. Status Resistensi Vektor Demam Berdarah Dengue (Aedes aegypti) Terhadap Insektisida Jenis Fenitrothion 1\% Di Kabupaten Kudus Provinsi Jawa Tengah Tahun 2017. Karya Tulis Ilmiah. Purwokerto : Politeknik Kesehatan Semarang Jurusan Kesehatan Lingkungan Purwokerto

Ratna Pramuditya. 2016. Efektivitas Beberapa Jenis Atraktan dalam Menangkap Telur Nyamuk Aedes Sp di Kelurahan Teluk Kecamatan Purwokerto Selatan Kabupaten Banyumas Tahun 2016. Skripsi. Purwokerto : Politeknik Kesehatan Kemenkes Semarang

Risky Supratiwi. 2016. Eksplorasi Status Resistensi Nyamuk Aedes aegypti Terhadap Insektisida Jenis Malathion 0,8\% Di Kabupaten Kudus Tahun 2017. Karya Tulis Ilmiah. Purwokerto : Politeknik Kesehatan Semarang Jurusan Kesehatan Lingkungan Purwokerto

Rizki Anindita, Tri Wulandari Kesetyaningsi. 2007. Deteksi Resistensi Larva Aedes aegypti dengan Uji Biokimia Berdasarkan Aktivitas Enzim Esterase di Kabupaten Bantul DIY. Jurnal Mutiara Medika Vol. 7 No 2: 88-94, at http://journal.umy.ac.id/index.php/mm/article/v iewFile/1661/1705 diakses pada tanggal 02 November 2017 pukul 19.30 WIB

Rizki Anindita, Tri Wulandari Kesetyaningsi. 2007. Deteksi Resistensi Larva Aedes aegypti dengan Uji Biokimia Berdasarkan Aktivitas Enzim Esterase di Kabupaten Bantul DIY. Jurnal Mutiara Medika Vol. 7 No 2: 88-94, at http://journal.umy.ac.id/index.php/mm/article/v iewFile/1661/1705 diakses pada tanggal 02 November 2017 pukul 19.30 WIB

Roy Nusa, Mara Ipa, Titin Delia, Marliah Santi. 2008. Penentuan Status Resistensi Aedes aegypti Dari Daerah Endemis DBD Di Kota Depok Terhadap Malathion. Jurnal Bultein Penelitian Kesehatan Vol. 36 No. 1, at http://ejournal.litbang.depkes.go.id/index.php/B PK/article/view/2154 diakses pada tanggal 2 November 2017 pukul 20.34 WIB
Shinta, Supratman Sukowati, Asri Fauziah. 2008. Kerentanan Nyamuk Aedes aegypti Di Daerah Khusus Ibukota Jakarta dan Bogor Terhadap Insektisida Malathion dan Lambdacyhalothrin. Jurnal Ekologi Kesehatan Vol 7 No. 1: 722731 , at http://ejournal.litbang.depkes.go.id/index.php/je k/article/view/1648 diakses pada tanggal 02 November 2017 pukul 19.30 WIB

Siwi Pramatama Mars Wijayanti, Dian Anandari, Arrum Firda Ayu Maqfiroch. 2017. Pengukuran Ovitrap Index (Oi) Sebagai Gambaran Kepadatan Nyamuk Di Daerah Endemis Demam Berdarah Dengue (DBD) Kabupaten Banyumas Jurnal Kesmas Indonesia, Vol. 9 No. 1, Hal 56-63, at http://jos.unsoed.ac.id/index.php/kesmasindo/ar ticle/view/228/200 diakses pada tanggal 19 April 2018 pukul 06.54 WIB

Soedarmo, Sumarmo Sunaryo Poorwo. 2009. Demam Berdarah (Dengue) Pada Anak. Jakarta: Penerbit Universitas Indonesia(UI-Press)

Soedarto. 2012. Demam Berdarah Dengue. Jakarta: Sagung Seto

Soegeng Soegijanto. 2006. Demam Berdarah Dengue edisi kedua. Surabaya : Airlangga University Press

Sunaryo, Bina Ikawati, Rahmawati, Dyah Widiastuti. 2014. Status Resistensi Vektor Demam Berdarah Dengue (Aedes aegypti) Terhadap Malathion 0,8\% dan Permethrin 0,25\% Di Provinsi Jawa Tengah. Jurnal Ekologi Kesehatan, Vol. 12, No.2, at http://ejournal.litbang.depkes.go.id/index.php/je k/article/view/3952 diakses pada tanggal 22 Oktober pukul 10.31 WIB

Suri Dwi Lesmana. 2010. Resistensi Aedes aegypti terhadap Insektisida Golongan Organofosfat. Jurnal Ilmu Kedokteran Vol.4 No.1, at https://ejournal.unri.ac.id/index.php/JIK/article/ view/4246/4075 diakses pada tanggal 03 Januari 2018 pukul 12.36 WIB

Tri Cahyono. 2018. Panduan Penulisan Skripsi. Purwokerto : Kementerian Kesehatan RI Politeknik Kesehatan Jurusan Kesehatan Lingkungan Purwokerto 